\title{
A New Vision of Management: Full Potential Management Model
}

Yuka Fujimoto, Deakin University, Australia

Charmine E.J. Hartel, University of Queensland, Australia

\begin{abstract}
This paper establishes the Full Potential Management (FPM) Model based upon the social model of disabilities coupled with principles of diversity management and disability-oriented human resource management. Despite the fact that the concept of management was once envisioned as having 'value to society' by improving the quality of life through efficient practices (Rimler, 1976), management literature has narrowly defined management as a means to gain increased productivity and achieve organizational goals, thus overlooking the social formation and implementation design for a better life (Diener \& Seligman, 2004; Small, 2004; Whitley 1989). Based upon the diversity literature, we propose that social-oriented diversity management principles and practices are the key to transforming management concepts from achieving organizational potential to achieving social aims that maximize the potential and quality of life of each person.
\end{abstract}

\section{INTRODUCTION}

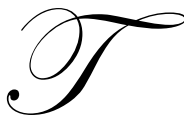

his paper establishes the Full Potential Management (FPM) Model based upon the social model of disabilities coupled with principles of diversity management and disability-oriented human resource management. Despite the fact that the concept of management was once envisioned as having 'value to society' by improving the quality of life through efficient practices (Rimler, 1976), management literature has narrowly defined management as a means to gain increased productivity and achieve organizational goals, thus overlooking the social formation and implementation design for a better quality of life (Diener \& Seligman, 2004; Small, 2004; Whitley 1989). Based upon the diversity literature, we propose that socially-oriented diversity management principles and practices are the key to transforming management concepts, from achieving organizational potential to achieving social aims that maximize the potential and quality of life of each person.

Currently, some definitions of management used in management literature include 'a process that involves co-ordinating resources (e.g., human, material, technological and financial) necessary for an organisation to achieve its goals (Small, 2004) and 'the construction, maintenance and improvement of an administrative system which coordinated and transformed resources into productive services' (Whitley, 1989). In this paper, we urge practitioners and scholars alike to re-evaluate the construct of management by transforming its vision from an organizationcentric vision to a social-centric vision, which concerns socio-economic sustainability and inclusion of every person. We propose that the vision of management should not only represent a single aim of each organization but also be a collective effort of organizations to ameliorate social division in communities and nations. In doing so, individuals, organizations, communities and nations will reach their maximum potential by learning form diversity.

Before we begin our discussion, we present the key terminologies used in this paper. We coined the term social disability to refer to an individual disability (mental or physical) that is fostered by a distorted social development process not by individual mental and physical attributes per se. We also coined the term social disablement to describe the unsuccessful management of a society in which every person is exposed to some form of social and/or physical obstacles that prevent them from reaching their full potential in life. By contrast, we have coined the term social enablement to refer to the successful management of society where every person is given equal opportunity and support from authorities to reach their full potential. 
In order to establish social-centric management that aims to harness the full potential of every person, the Model advocates top managers to: (1) value the differences more than the similarities in each organization; (2) embrace disability-open human resource management (HRM) practices and policies; (3) put forth a greater concerted effort with other managers from other social constituents; (4) simultaneously detect any social gaps among social constituents, and organizational gaps in principles of diversity management and associated disabilityopen HRM policies and practices; and (5) devise, implement and evaluate management plans for organizations and society to work toward reaping the full potential of every person.

We develop our model as follows. First, we define multiple dimensions of disabilities and introduce the social disability as a central focus of this paper. Second, the social model of disability is explicated by the sociopsychological theories of similarity attraction (Byrne, 1971), social categorization processes (Tajfel, 1972), social identity processes (Tajfel, 1974; Tajfel \& Turner, 1986), and status characteristics theories (e.g., Berger, Fisek, Norman \& Zelditch, 1977). Third, managing social disability is explained through the principle of socially-oriented diversity management, coupled with the application of disability-oriented HRM. We conclude by presenting the Full Potential Diversity Management Model with propositions, discussion and conclusion.

\section{DEFINITION OF DISABILITY}

Disability is defined as one aspect of a person that is impaired (i.e., missing, damaged, deficient), disabled (i.e., inability to perform life activities), and handicapped (i.e., social, personal or physical obstacles, which inhibit a person's chance of success) (Miller \& Sammons, 1999). Based upon this definition, disability includes both visible (i.e., physical) and invisible (i.e., psychological) dimensions. The handicap aspect of the definition of disability vividly communicates that disability is, in part, created by obstacles that can be redressed by others (cf. Abberley, 1987, p.12). Notably, data indicates that most disabilities in workplaces are often 'hidden' disabilities such as psychological stress, disorder, heart conditions and back-related injuries, which are silently calling for their opportunities for enablement (Lee, 1996). For example, workplace stress is costing the Australian economy $\$ 14.81$ billion a year, and the number of stress-related insurance claims has almost doubled while other claims have reduced significantly between 1996 and 2004 (Australian Safety and Compensation Council, 2007).

In short, disability emanates from two sources. First, from an individual's mental and/or physical state and, second, disability arises from the political decisions of individuals, particularly those in top management positions. In other words, disability is also an obstacle created by a decision-making process of management that prevents individuals from reaching their full potential. The substantial number of disabilities at work is related to the manifestations of management that create the "disabling" elements rather than the "enabling" elements for employees (Abberley, 1987; Harlan \& Robert, 1998). Primary prevention, therefore, calls for the top management to develop preventive, ameliorative techniques such as making changes in working methods and in their use of technology, and to implement "enabling" HRM initiatives (Abberley, 1987). This will be discussed in more detail later.

\section{SOCIAL MODEL OF DISABILITY: SOCIAL IDENTITY AND SOCIAL CATEGORIZATION PROCESS}

This paper draws upon the social model of disability (e.g., Abberley, 1987; Barnes, Mercer, Shakespeare, 1999; Finkelstein, 1980; Hales, 1986; Hahn, 1988, Linton, 1998; Oliver, 1990, 1996), which articulates that disability is an outcome of societal process, which involves political power, organizational attitudes, social structure and social relations. For example, research findings imply that discriminatory behaviors against people with disabilities are socially learned rather than innate biological consequences. For example, children don't react negatively to abnormal observable characteristics until they are at least 11 years old (New Society, 1985). Thus, the perceived inferiority of people with disabilities seems to be a result of distorted social development (Abberley, 1987). We call the individual disability (both mental and physical), fostered by a distorted social development process, "social disability".

Until recently, the model of disability generally called for individuals with disabilities to remedy their disabilities through the help of social constituents, thus ignoring the need to change the social phenomenon that minimizes their rights and limits their opportunities (Mackelprang \& Salsgiver, 1999). For example, the medical 
and/or mental health and vocational model of disability regards the individual with disabilities as a passive recipient of medical and vocational treatment. The educational model of disability regards education as a source of remedial learning and of improving the behavior of those with disabilities (Mackelprang \& Salsgiver, 1999). In contrast, the diversity model of disability articulates the collective social responsibility for providing opportunities for people with disabilities in the social environment (Mackelprang \& Salsgiver, 1999). Consequently, we contend that a principle of social-oriented management is the fundamental catalyst for reducing social disabilities in the workplace and in society at large.

Although disabilities manifested by individual attributes have become common knowledge, the extent to which the management of social processes can reduce the level of social disability is yet to be fully acknowledged, examined or remedied. First and foremost, this paper advocates that a vision and goal of management need a notion of concerted effort of the managers and leaders to alleviate social disabilities within communities and workplaces. In other words, depending on the societal values and attitudes of those in management positions, the same individual who is seen as severely disabled in one place can instead be valued in another (cf. Woodhams \& Danieli, 1997). The socio-psychological process applicable to the social model of disability management is explained by the social categorization, social identity and social characteristics theories.

\section{Social Categorization Theory}

The theory of social-categorization states that people tend to categorize themselves and others into various social categories, namely, in-group and out-group membership (Turner \& Oakes, 1989). The in-group/out-group distinction activates negative stereotypes and prejudices that cause group members to make biased attributions (Allport, 1954; Hewstone \& Ward, 1985; Jackson et al., 1993; Taylor \& Jaggi, 1974). According to the social model of disability, the term disability is categorized by a complex web of social judgements, institutional structures and policy-makers (Gordon \& Rosenblum, 2001). The categorization of people as "disabled" insinuates the complex mix of social and institutional attitudes that create the culture of ignorance, misconception, stereotyping, and prejudices toward certain individuals (Harlan \& Robert, 1998; Taylor, 1989). The culturally-determined ways of management, therefore, are in danger of devaluing, oppressing and excluding people from the work environment and from society at large (Mackelprang \& Salsgiver, 1999). Consequently, people with social disabilities tend to share a distinctive and different cultural way of life from those without disabilities.

This is not a trivial issue. For example, the U.S. Equal Employment Opportunity Commission Report in 2009 indicated that disability discrimination claims have increased from 15,864 in the year 2000 to 17,737 in the year 2007, a $12 \%$ increase. Furthermore in the U.K., $60 \%$ of people with disabilities experience unemployment compared to $20 \%$ for people without disabilities (Demaret, 2004). In Australia, one in five Australians are reported to have some form of disability and their work participation is reported, in the year 2004, as $53.2 \%$ compared with $80.6 \%$ of those without disability (Australian Bureau of Statistics, 2004). The social phenomenon of people with disabilities having significantly lower levels of employment, job status, and compensation than people without disabilities implies ignorance by management in dealing with issues of social disability as a whole (Braddock \& Batchelder, 1994). As people with management power have the most dominant influence on the social categorization process in any social context, their concerted effort is expected to be a fundamental conduit to counteract the rising level of social disability in today's workforce (Nordstrom et al., 1998).

\section{Social Identity Theory}

Social identity theory further states that people tend to strive to achieve or maintain a positive self-image as a result of a favorable comparison between their social category and other groups (Tajfel, 1974; Tajfel \& Turner, 1986). Consequently, people without social disabilities are expected to maintain their social identity by associating with others without social disabilities, which systematically eliminates people with social disabilities (e.g., low income and less educated groups) from their social environment. This phenomenon infers a power structure of privileged non-socially disfranchised members consciously or unconsciously establishing the criteria for identifying who are disabled, and their consequent eligibility for employment, services and support (Gordon \& Rosenblum, 2001). Ironically, research indicates that even when employed, people with disabilities are likely to remain in entrylevel positions or unskilled and low-earning positions, resulting in significant wage gaps in comparison with their non-disabled counterparts (Jones, 1998). 


\section{Status Characteristics Theory}

Furthermore, status characteristics theory (Berger, Fisek, Norman \& Zeldith, 1977; Humphreys \& Berger, 1981; Kirton \& Greene, 2000:73) explains the status-organizing process of task unit members by which members of different social types (e.g., gender, race, prestige positions and education) become the basis of the individual evaluation and expectation of the social and performance worth of other members. Producing a sense of power order in the unit, leads to behavioral inequalities (e.g., suppression of voice and reduced quality of communication) and sub-optimal performance.

We contend that the social categorization, social identity and status characteristics processed by top management would, first and foremost, determine the social divide between people with and without social disabilities, creating a long-lasting discriminatory workplace and society. We advocate that, in order to establish the social enablement management process, top managers would need to adopt certain socially-oriented management perspectives based upon the principles of diversity management and disability-oriented HRM. This will be discussed next.

\section{DIVERSITY MANAGEMENT}

To date, research found that legal interventions such as Equal Employment Opportunity (EEO) legislation, Affirmative Action (AA) and the Americans with Disabilities Act (ADA) have been viewed as ambiguous and ineffective in dealing with the consequences of social disability (Blanck, 1997; Gilbert \& Ivancevich, 2000, 2001; Gilbert \& Stead 1999; Heilman, Block, \& Lucas, 1992; Yakura, 1996). Although ADA fosters work justice through the fair treatment of workers with disabilities (Huss, 1993), organizations still devalue the work of disabled workers and adopt resisting strategies toward accommodating them at work (Harlan \& Robert, 1998; Miceli, Harvey \& Buckley, 2001). The ineffectiveness of the Act has become evident through the gradual increase in disability discrimination claims in the U.S., with a similar result in Australia (AHRC, 2009; EEOC, 2009).

We argue that managers, therefore, need to initiate greater social sensitivity for managing diversity, which goes beyond the necessary legal compliance of organizations (Gilbert \& Ivancevich, 2000). Underpinning diversity management is the willingness or unwillingness of top management to reduce social disabilities within workplaces and surrounding communities (Abberley, 1987; Mor Barak, 2005). Unlike EEO, AA and ADA, which are legal obligations to encourage equality in attitude and increase the number of different identity groups in the workplace, managing diversity aims to assist organizations to deal with the root causes of issues surrounding difference, such as stereotypes, prejudice and inequality which hinder the development of everyone's full potential (Thomas, 2001).

Diversity management is, in other words, a managerial value-driven strategy to maximize the potential of all employees, unhindered by group identities such as race, gender, age, and disability (Ivancevich \& Gilbert, 2000; cf. Kossek \& Lobel, 1996). We argue that a general philology of management needs to include greater diversity open and embracive attitudes, values and beliefs to counteract the phenomenon of social disabilities (Arredondo, 1996; Berger, Soper, \& Foster, 2002; Härtel \& Fujimoto, 1999; Reichenberg, 2001). Management that offers full support to struggling workers (e.g., giving time, resources, and opportunities) and endeavors to reduce any form of social disability (e.g., changing work designs instead of laying off workers; conducting educational and learning sessions to learn about each others' struggles and to implement solutions) would help historically marginalized and struggling workers to continually strengthen their sense of belonging. These social-oriented management interventions would reduce the propensity of workers to fall into the category of people with social disabilities.

To date, research findings reveal that top management tends to classify the disability exclusively within the individual and little attention has been paid to the external restrictions in the individual's social and work environment (Hahn, 1991, cited in Mackelprang \& Salsgiver, 1999). For example, recent research found that although multiple work barriers are faced by employees with arthritis, only a small number of organizations make any form of work modification (Allaire \& LaValley, 2003). As the attitudes of people with management power are inferred as championing the causes of social disabilities (Klimoski \& Donahue, 1997), changes in their attitudes could ameliorate social disabilities in workplaces and society. We consider social centric orientation in managing diversity is the key to dealing with the increasing dimensions of social disabilities created by societal phenomena 
such as the immense impact of the global economy crisis on the working-poor population (Abberley, 1987; Harlan \& Robert, 1998). This will be discussed next.

\section{SOCIAL ORIENTATION OF MANAGING DIVERSITY}

Managing diversity implies a holistic management philosophy ranging from the CEO's leadership, values and support through to human resource initiatives and the organization's community-wide communication (Gilbert \& Ivancevich, 2000; Stone \& Colella, 1996; Maddock, 1995; Sayce, 2003). Along with the holistic landscape of diversity management, a diversity vision of management can expand into active and dynamic social exchange processes among the constituents of work management, accompanied by diversity leadership and diversity-oriented human resource initiatives (Klimoski \& Donahue, 2001). The social constituents of workplace management would encompass all possible stakeholders in managing social disabilities, such as government bodies, business enterprises, universities, medical institutions, people with and without social disabilities, and HRM managers. As people with social disabilities are often under-represented in the disability academic research conducted on their behalf, there is a need to fill in the gap between the rhetoric and social reality of management of disabilities (Kitchin, 2000).

We propose that workplace management underpinned by a social orientation of managing diversity entails detecting the gaps at the social and organizational levels. First, social gaps are detected by on-going interaction among the social constituents of management to ameliorate social disabilities. The gaps may include lack of government funding and technological innovations, medical and counseling support, or the lack of the voices of disabled people in policy-making (see Figure 1). Second, the organizational gaps are detected by on-going investigation of the way differences are managed within organizations, and of which disability-open HRM policies and practices have been effective or ineffective (see Figure 1).

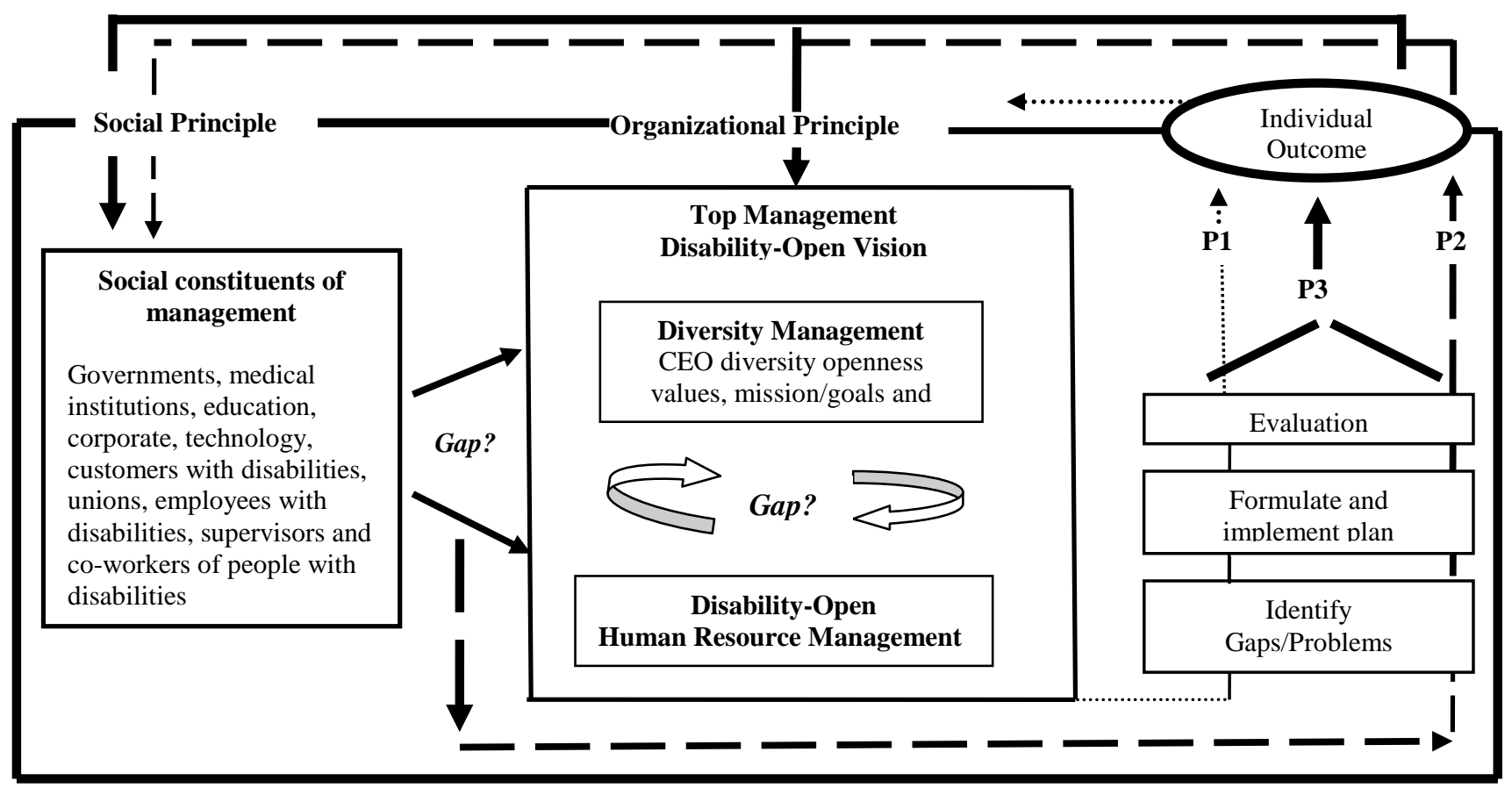

Figure 1: Full Potential Management Model

In other words, each social constituent of workplace management is encouraged to engage in an on-going network among the social stakeholders of social disabilities to plan, implement, evaluate (or measure) and to fill in the social gaps. At the same time, managers of each social constituent are required to engage in the on-going investigation of their management of differences and their HRM policies and practices. The model posits the mechanism of each organization and social entity continuously reducing the level of social disabilities in 
organizations and societies. This socially-oriented management decision-making process would not only reduce the level of social disabilities but also enhance the well-being and productivity of societies and organizations (see Figure $1)$.

\section{DISABILITY-OPEN HUMAN RESOURCE MANAGEMENT}

Diversity management is heavily associated with HRM policies and practices (Ivancevich \& Gilbert, 2000; McMahan, Bell, \& Virick, 1998). Diversity management may also be interpreted as the systematic and planned commitment by organizations to recruit, retain, reward and promote a diverse mix of employees (Ivancevich \& Gilbert, 2000; Thomas, 1999) which, in turn, fosters a climate of diversity openness. Nevertheless, the effect of social disability on individuals, groups and organizations is complex and ambiguous (cf. Benschop, 2001; Klimoski \& Donahue, 1997). Therefore, organizations require an interplay of disability-open HR policies and practices, which is coherently supported by internal (e.g., top management and disability panels) and external social constituents of disability management, such as social services, medical providers, government, unions, and technologies (McMahan et al., 1998).

Notably, despite over 63,000 employment discrimination claims relating to HR issues being made in the first four years of ADA's existence, little research in HRM has focused on disability (Bowe, 1992; Braddock \& Backelder, 1994; Cash \& Kilcullen, 1985; Colella \& Varma, 2001; Roehling, 1999; Miceli, Harvey, \& Buckley, 2001; Healey, 2000; Hernandez, Keys, Balcazar \& Drum, 1998; Lee, 1996; Stone \& Colella, 1996; Stone, Stone, \& Dipboye, 1992; Woodhams \& Danieli, 2000).

We propose that disability-open HRM policies based on the social orientation of diversity management can create a non-discriminatory, ethical, and respectful organization that also fosters the achievement of the business's vision and objectives (cf. Curtis \& Scott, 2003; Sayce, 2003; Goss, Goss \& Adam-Smith, 2000). Disability-open HRM refers to HRM policies and practices that promote disability-open values in an organization, thereby overcoming social stereotypes and prejudices in the workplace. Disability-open HRM is exhibited by disabilityembracive recruitment and selection processes (e.g., technology to enhance disability job placement and matching activities); providing disability-friendly facilities in the workplace supported by rehabilitation centers and social services (Stock, Davies, Secor, \& Wehmeyer, 2003); special consideration of disabilities in performance appraisal and reward processes (e.g., extra regular feedback and assistance for disabled workers); on-going training to rehabilitate workers with disabilities as well as to train workers (i.e., top management, supervisors and co-workers) to minimize their stereotypes and prejudices in the workplace (Klimoski \& Donahue, 1996; Jones, 1998); monitoring the well-being (physical and mental) of individuals supported by industrial engineers and risk management specialists; communicating the value of disabled workers in the workplace and the community; and establishment of a disability advisory panel (Klimoski \& Donahue, 1997). Disability-open HRM fostered by a social orientation of diversity management would promote a disability-open climate (Kossek \& Zonia, 1993), thereby contributing toward unleashing the full potential of each employee in an organization.

Moreover, disability-open HRM policies and practices that reflect an increasingly diverse workforce warrant good public relations, employee loyalty, productivity, and decreased staff-turnover (Cox \& Tung, 1997; Morrison \& Herlihy, 1992, cited in Gilbert \& Ivancevich, 2001). For example, IBM was publicly praised for the establishment of a national support centre for persons with disabilities, which provides information about how technology can assist people with disabilities (Anonymous, 2007). Thus, disability-open HRM policies and practices vividly communicate top management's intention to ameliorate the level of social disabilities in the workplace and society as a whole.

\section{FULL ENABLEMENT MANAGEMENT (FEM) MODEL}

Disability research indicates an enormous lack of coordinated effort among the key social constituents of workplace management (i.e., government, unions, disability institutions/agencies, employees with disabilities, and medical providers) to minimize the effects of social disabilities. This co-ordination gap mirrors other major findings in the shortcomings of management, namely, a lack of awareness of disabled workers' needs, a lack of funded services, inflexible bureaucracy in the workplace to deal with disability, fear and ignorance of disabilities in the 
community, overlooking the talent of people with disabilities, and focusing on dealing with disability crises rather than instigating long-term strategic management plans (Healey, 2000). Research indicates that even if negative stereotypes of people with disabilities exist in the community, disability-open management at a societal level would compel organizations to exhibit socially-acceptable behaviors, that is, to provide a good working environment for people, aiming to minimize any form of social disability discrimination (Parry, 1995).

Today, in order to address these issues, organizations would need to adapt the Full Enablement Management (FEM) Model for their situation. The FEM model advocates: (1) greater concerted effort among the social constituents of workplace management; (2) valuing diversity (e.g., workers with social disabilities) at the top management level; (3) embracing disability-open HRM based on a social orientation of diversity management; and (4) simultaneously detecting gaps/problems (among social stakeholders, diversity management and disability-open HRM) and devising, evaluating and implementing plans to develop excellent organizational health (i.e., emotional, mental and physical) while ensuring social justice (cf. Curtis \& Scott, 2003). Although, to date, the concerted effort of stakeholders in management has been proposed as a system to mitigate social disability in the workplace (Agocs \& Burr, 1996; Klimoski \& Donahue, 1997), we posit that a "process" approach rather than a "system" approach is necessary to continuously develop a social-disability-free society and work environment (see Figure 1).

Thus, we present the following propositions:

Proposition 1: Individuals will fulfill their potential and maintain physical and mental well-being when organizations identify organizational gaps, and formulate and implement disability-open HRM policies and practices which are continually evaluated for their effectiveness at the individual level.

Proposition 2: Individuals will fulfill their potential and maintain physical and mental well-being when the social constituents of management collectively identify social gaps, and formulate and implement disability-open HRM policies and practices across organizations which are continually evaluated for their effectiveness at the individual level.

Proposition 3: Socially-oriented management formulation and implementation of processes will have a greater positive effect on individual employee's abilities, and physical and mental well-being than the formulation and implementation of organizational-oriented management processes over the long-term.

\section{DISCUSSION AND CONCLUSION}

We advocate that the implementation of the FEM model would lead to the amelioration of "social disability". The paper advocates that contemporary management largely ignores its responsibility to solve a wide range of societal concerns which, at present, unmistakably encompass social disabilities caused, in part, by today's controversial practices such as escalating employee redundancies and the stereotyping of "the ideal employee". Contemplating today's societies with widening social divisions, management scholars and practitioners are called to revise the vision and key tenet of management once again. We advocate that management should not only be defined by an operational view point alone, but also include a concerted effort by the social constituents of management to alleviate social disabilities in the workplace and society. Those in top management positions hold economic power over social relations and structures and, if not careful, have the ability to destroy people's lives which, in turn, produces dysfunctional organizations and societies (cf. Rosen, 1984; Willmott, 1984). We propose that managers executing policies and practices in light of social concerns, could ameliorate the effects of numerous medical (e.g., stroke, heart-attack, back injuries, cancer) and psychological (e.g., stress, depression, panic disorders) disabilities, which are well over-represented in today's workforce (see Diener \& Seligman, 2004). We conclude this paper by reiterating the importance of future management research being more focused on how to achieve all employees' full potential rather than only on organizational visions and goals. 


\section{AUTHOR INFORMATION}

Dr. Yuka Fujimoto is a senior lecturer in the School of Management and Marketing, Deakin University. Her research interest lies in the area of diversity-oriented participation, social inclusion and human-oriented human resource management education for current and future managers. She acts as a regular reviewer for Human Resource Management and serves in a Reviewers Panel of the Research and Practice in Human Resource Management (RPHRM) Journal. She is also a co-author of Human Resource Management Education Book.

Dr. Charmine E.J. Härtel is Professor of Human Resource Management and Organizational Development and Management Cluster Leader (Research) in the UQ Business School at The University of Queensland, Brisbane Australia. She has 27 years of experience in the public and private sector including consultancies in Australia, Europe, Asia and the U.S. and is recognized internationally as a leading expert in the areas of organizational and employee development, diversity management and social inclusion, leadership development and employee wellbeing. Professor Härtel's publications feature in books and over 70 refereed journal articles, including Academy of Management Review, Journal of Applied Psychology, Leadership Quarterly, Journal of Management and Human Resource Management Review. She is also the author (with Dr. Fujimoto) of the wholly original Australian textbook Human Resource Management: Transforming Theory into Innovative Practice.

\section{REFERENCES}

1. Abberley, P. (1987). The concept of oppression and the development of a social theory of disability. Disability Handicap \& Society, 2, 5-19.

2. Agocs C. and Burr C. (1996). Employment equity, affirmative action and managing diversity: assessing the differences, International Journal of manpower, 17 (4), 30-45.

3. Allaire, S. H., \& LaValley, M. P. (2003). Work barriers experienced and job accommodations used by persons with arthritis and other rheumatic diseases. Rehabilitation Counseling Bulletin, 46(3), 143-156.

4. $\quad$ Allport, G. W. (1954). The nature of prejudice. Cambridge, MA: Addison-Wesley.

5. Anonymous (2007). CRS Australia. Australian Government. Website accessed on 23/2/2009 http://www.crsaustralia.gov.au/local_employer_takes_diversitywork_award_lend_lease.htm.

6. Arredondo, P. (1996). Successful diversity management initiatives: A blueprint for planning and implementation.

7. Australian Human Rights Commission (2009). Annual report www.humanrights.gov.au/about/publications/annual_reports/2008_09/. 19.01.10

8. Australian Bureau of Statistics. (2004). Disability Australia, 2003. Commonwealth Government Printer, Canberra, ACT.

9. Australian Safety and Compensation Council (2007), Compendium of Workers' Compensation Statistics Australia 2004-05.

10. Barnes, C., Mercer, G., Shakespeare, T. (1999). Exploring Disability: A sociological introduction. Cambridge, Polity Press.

11. Benschop, Y. (2001). Pride, prejudice and performance: relations between HRM, diversity and performance. Human Resource Management, 12(7), 1166-1181.

12. Berger, J., Fisek, M.H., Norman, R.Z., \& Zelditch, M. (1997). Status Characteristics and expectation states: A graph-theoretical formulation. In J. Berger (Eds.), Status characteristics and social interaction: An expectations states approach (pp. 91-134). New York: Elsevier.

13. Berger, V., Soper, B., \& Foster, T. (2002). Unintended negative effects of diversity management. Public Personnel Management, 31(2), 239-251.

14. Blanck, P. D. (1997). The economics of employment provisions of the Americans with Disabilities Act: Part I-Workplace accommodations. DePaul Law Review, 46, 877-914.

15. Bowe, F. (1992). Adults with disabilities: A portrait. Washington, DC: President's Committee on Employment of People with Disabilities.

16. Braddock, D., \& Batchelder, L. (1994). The glass ceiling and persons with disabilities. Washington. DC: Glass Ceiling Commission, U.S. Department of Labor.

17. Byrne, D. (1971). The Attraction Paradigm. New York: Academic Press. 
18. Cash, T. F., \& Kilcullen, R. N. (1985). The eye of the beholder: Susceptibility to sexism and beautyism in the evaluation of managerial applicants. Journal of Applied Social Psychology, 15, 591-605.

19. Colella, A., \& Varma, A. (2001). The impact of subordinate disability on leader member exchange relationships. Academy of Management Journal. 44(2), 304-315.

20. Curtis, J., \& Scott, L. (2003). Making the connection. Benefits Canada. 27(4), 75-77.

21. Demaret, L. (2004). Disability-the human cost of discrimination. In Labour Education 2004/4 No.137 (Eds.), Trade unions and workers with disabilities: Promoting decent work, combating discrimination, (pp.11-16). Geneva: International Labour Organization.

22. Diener, E., \& Seligman, E. P. (2004). Beyond Money: Toward an Economy of Well-being. American Psychological Society, 5(1), 1-31.

23. Equal Employment Opportunity Commission U.S. (2008). Website accessed on 13/02/2009. http://www.eeoc.gov/stats/ada-charges.html

24. Finkelstein, V. (1980). Attitudes and Disabled People. New York: World Rehabilitation Fund.

25. Gilbert, J. A. \& Ivancevich, J. M. (2000). Valuing diversity: A tale of two organisations. Academy of Management Executives, 24(1), 93-105.

26. Gilbert, J. A. \& Ivancevich, J. M. (2001). Effects of diversity management on attachment. Journal of Applied Social Psychology, 31(7), 1331-1349.

27. Gilbert, J. A. \& Stead, B. A. (1999). Stigmatisation revisited: Does diversity management make a difference in applicant success? Group and Organisation Management, 24(2), 239-256.

28. Gordon, B. O., \& Rosenblum, K. E. (2001). Bringing??? disability into the sociological frame: A comparison of disability with race, sex, and sexual orientation statuses. Disability and Society, 16(1), 5-19.

29. Goss, D., Goss, F. and Adam-Smith, D. (2000). "Disability and Employment: Comparative Perspectives". International Journal of Human Resource Management, 11(4), 807-821.

30. Hahn, H. (1988). The politics of physical differences: Disability and discrimination. Journal of Social Issues, 44, 59-47.

31. Hales, G. (1986). Beyond Disability: Towards an Enabling Society. London: Sage.

32. Harlan, S., \& Robert, P. (1998). The social construction of disability in organizations: Why employers resist reasonable accommodation. Work and Occupations: An International Sociological Journal, 25(4), 397-435.

33. Härtel, C. E. J., \& Fujimoto, Y. (1999). Explaining why diversity sometimes has positive effects in organisations and sometimes has negative effects in organisations: The perceived dissimilarity-openness moderator model. In L. N. Dosier \& J. B. Keys (Eds.). Academy of Management Best Papers Proceedings (CD-ROM). Pleasantville, NY: Academy of Management.

34. Healey, J. (2000). Disability and Discrimination. NSW: Spinney Press.

35. Heilman, M. E., Block, C. J., \& Lucas, J. A. (1992). Presumed incompetent? Stigmatisation and affirmative action efforts. Journal of Applied Psychology, 77, 536-544.

36. Hernandez, B., Keys, C., Balcazar, F., \& Drum, C. (1998). Construction and validation of the disability rights attitude scale: Assessing attitudes toward the Americans with Disability Act (ADA). Rehabilitation Psychology, 43, 203-218.

37. Hewstone, M., \& Ward, C. (1985). Ethnocentrism and causal attribution in Southeast Asia. Journal of Personality and Social Psychology, 48(3), 614-623.

38. Huss, A. C. (1993). The ADA agenda: Attitude adjustment. Compensation \& Benefits Management. 9(2), 4-18.

39. Humphreys, P., \& Berger, J. (1981). Theoretical consequences of the status characteristics formulation. American Journal of Sociology, 86, 953-983.

40. Ivancevich, J. M., \& Gilbert, J. A. (2000). Diversity management-time for a new approach. Public Personnel Management, 29(1), 75-92.

41. Jackson, S. E., Stone, V. K., \& Alvarez, E. B. (1993). Socialization amidst diversity: Impact of demographics on work team oldcomers and newcomers. In L. L. Cumming \& B. M. Staw (Eds.), Research in organisational behaviour. (Vol. 15, pp. 45-109). Greewich, CT: JAI Press.

42. Jones, D (1998). "Possibilities of transformation: discourses of difference in organisational communication", University of Waikato, Hamilton.

43. Kirton, G., \& Greene, A.M. (2000). The Dynamics of Managing Diversity - A Critical Approach. Oxford, England: Butterworth Heinemann. 
44. Kitchin, R. The researched opinions on research: disabled people and disability research. Disability and Society, 15(1), 25-47.

45. Klimoski, R., \& Donahue, L. (1997). HR strategies for integrating individuals with disabilities into the work place. Human Resource Management Review, 7(1), 109-138.

46. Kossek, E. E., \& Lobel, S. A. (1996). Managing Diversity: Human Resource strategies for transferring the work place. Massachusetts: Blackwell.

47. Lee, B. A. (1996). Legal requirements and employer responses to accommodating employees with disabilities. Human Resource Management Review, 6(4), 231-251.

48. Kossek, E.E., \& Zonia, S.C. (1993). Assessing diversity climate: A field study of reactions to employer efforts to promote diversity. Journal of Organisational Behaviour, 14, 61-81.

49. Linton, S. (1998). Disability studies: Not disability studies. Disability and Society, 13, 525-541.

50. Mackelprang, R. W., \& Salsgiver, R. O. (1999). Disability: a diversity model approach in human service practice. Pacific Grove, CA: Brooks/Cole.

51. McMahan, G. C., Bell, M. P., \& Virick, M. (1998). Strategic human resource management: Employee involvement, diversity, and international issues. Human Resource Management Review, 8(3), 193-214.

52. Maddock, S (1995). Rhetoric and reality: The business case for equality and why. Women in Management Review, 10(1), 14-22.

53. Miceli, N. S., Harvey, M., \& Buckley, M. R. (2001). Potential discrimination in structured employment interviews. Employee Responsibilities and Rights Journal. 13(1), 15-38.

54. Miller, N. B. \& Sammons, C. C. (1999). Everybody's different: Understanding and changing our reaction to disabilities. Baltimore: Paul H. Brookes Publishing Co.

55. Mor-Barak, M. E. (2000). The inclusive workplace: An ecosystems approach to diversity management. Social Work, 45(4), 339-352.

56. Mor Barak, M. E. (2005). Managing diversity: Toward a globally inclusive workplace. Thousand Oaks, CA: Sage Publications.

57. Nordstrom, C.R., Huffaker, B.J., \& Wilhams, K.B. (1998). When physical disabilities are not liabilities: The role of applicant and interviewer characteristics on employment interview outcomes. Journal of Applied Social Psychology, 28, 283-306.

58. Oliver, M. (1990). The Politics of Disablement. Basingtoke: Macmillan.

59. Oliver, M. (1996). Understanding Disability: From Theory to Practice. London: Macmillan.

60. Parry, J. (1995). Mental disability Law: A primer $5^{\text {th }}$ ed. American Bar Association, Washington, DC.

61. Reichenberg, N. E. (2001, May). Best practices in diversity management. Paper presented at the United Nations Expert Group Meeting on Managing Diversity in the Civil Service, New York.

62. Rimler, G. W. (1976). The death of management - Search for causes. Academy of Management Review, 1(2) 126-128.

63. Roehling, M. V. (1999). Weight-based discrimination in employment: Psychological and legal aspects. Personnel Psychology, 969-1016.

64. Rosen, M. (1984). Myth and reproduction: The conceptualisation of management theory, method and practice. Journal of Management Studies, 21(3), 303-321.

65. Sayce, L. (2003). Beyond good intentions: Making anti-discrimination strategies work. Disability and Society, 18(5), 625-642.

66. Small, M. W. (2004). Philosophy in management: A new trend in management development. Journal of Management Development, 23(2), 183-196.

67. Stock, S. E., Davies, D. K., Secor, R. R., \& Wehmeyer, M.L. (2003). Self-directed career preference selection for individuals with intellectual disabilities: Using computer technology to enhance selfdetermination. Journal of Vocational Rehabilitation, 19, 95-103.

68. Stone, D. L., \& Colella, A. (1996). A model of factors affecting the treatment of disabled individuals in organizations. Academy of Management Review. 21(2), 352-401.

69. Stone, E. F., Stone, D. L., \& Dipboye, R. L. (1992). Stigmas in organizations: Race, handicaps, and physical unattractiveness. In K. Kelley (Ed.), Issues, theory and research in industrial and organizational psychology, 385-444. Amsterdam, The Netherlands: Elsevier.

70. Tajfel, H. (1972). Social categorisation [English ms. of La categorisation sociale]. In S. Moscovici (Eds.), Introduction à la psychologie sociale (Vol. 1, pp. 272-302). Paris: Larousse.

71. Tajfel, H. (1974). Social identity and intergroup behaviour. Social Science Information 13,65-93. 
72. Tajfel, H., \& Turner, J. C. (1986). The social identity theory of intergroup behaviour. In S. Worchel and W. G. Austin (Eds.), Psychology of intergroup relations. Chicago: Nelson Hall.

73. Taylor, C. (1989). Sources of the Self: The Making of the Modern Identity. Cambridge, Mass: Harvard University Press.

74. Taylor, D. M., \& Jaggi, V. (1974). Ethnocentrism and causal attribution in a south Indian context. Journal of Cross Cultural Psychology, 5(2), 162-171.

75. Thomas, D. A. (1999). Mentoring and Diversity in Organizations: The Importance of Race and Gender in Work Relationships. In A. Daly (Eds.), Diversity in the Workplace: Issues and Perspectives. National Association of Social Workers Press. City and country?

76. Thomas, R. R. (2001). From Affirmative Action to Affirming diversity, (Eds.), Harvard business review on managing diversity. (pp.1-32). Massachusetts: Harvard Business School Publishing Corporation.

77. Turner, J.C., \& Oakes, P. J. (1989). Self-categorisation theory and social influence. In P. B. Paulus (Eds.), Psychology of group influence (pp 233-275). Hillsdale, New Jersey: Lawrence Erlbaum Associate, Inc.

78. Whitley, R. (1989). On the nature of managerial tasks and skills: Their distinguishing characteristics and organization. Journal of Management Studies, 21, 349-368.

79. WHO. The bare facts. Geneva, World Health Organisation, 2008. (url: http://www.who.int/mental_health/en, accessed 18/02/09).

80. Willmott, H. (1984). Images and ideals of managerial work: A critical examination of conceptual and empirical accounts. Journal of Management Studies, 21,349-368.

81. Wilson, H. W. (1999). Social justice and diversity. Quest (Champaign, III). 51(4), 305.

82. Woodhams, C., \& Danieli, A. (2000). Disability and diversity-a difference too far? Personnel Review, 29, 402-416.

83. Yakura, E. K. Year1996??? EEO law and managing diversity. In E. E. Kossek \& S. A. Lobel (Eds.), Managing diversity: human resource strategies for transferringtransforming??? the work place (pp. 2549). Massachusetts: Blackwell. 


\section{NOTES}

